\title{
Gene Expression Profiles Identify Inflammatory Signatures in Dendritic Cells
}

\author{
Anna Torri ${ }^{19}$, Ottavio Beretta ${ }^{29}$, Anna Ranghetti ${ }^{1}$, Francesca Granucci ${ }^{1}$, Paola Ricciardi-Castagnoli ${ }^{2}$, \\ Maria Foti ${ }^{1 *}$
}

1 Department of Biotechnology and Bioscience, University of Milano-Bicocca, Milan, Italy, 2 Singapore Immunology Network, Singapore, Singapore

\begin{abstract}
Dendritic cells (DCs) constitute a heterogeneous group of antigen-presenting leukocytes important in activation of both innate and adaptive immunity. We studied the gene expression patterns of DCs incubated with reagents inducing their activation or inhibition. Total RNA was isolated from DCs and gene expression profiling was performed with oligonucleotide microarrays. Using a supervised learning algorithm based on Random Forest, we generated a molecular signature of inflammation from a training set of 77 samples. We then validated this molecular signature in a testing set of 38 samples. Supervised analysis identified a set of 44 genes that distinguished very accurately between inflammatory and non inflammatory samples. The diagnostic performance of the signature genes was assessed against an independent set of samples, by qRT-PCR. Our findings suggest that the gene expression signature of DCs can provide a molecular classification for use in the selection of anti-inflammatory or adjuvant molecules with specific effects on DC activity.
\end{abstract}

Citation: Torri A, Beretta O, Ranghetti A, Granucci F, Ricciardi-Castagnoli P, et al. (2010) Gene Expression Profiles Identify Inflammatory Signatures in Dendritic Cells. PLoS ONE 5(2): e9404. doi:10.1371/journal.pone.0009404

Editor: Patricia T. Bozza, Fundação Oswaldo Cruz, Brazil

Received September 25, 2009; Accepted February 4, 2010; Published February 24, 2010

Copyright: (c) 2010 Torri et al. This is an open-access article distributed under the terms of the Creative Commons Attribution License, which permits unrestricted use, distribution, and reproduction in any medium, provided the original author and source are credited.

Funding: This work was supported by the grants from European Commission 6th Framework Program (AIDS-CoVAC), the Italian Ministry of Education and Research PRIN-COFIN 20077NFBH8_003. The funders had no role in study design, data collection and analysis, decision to publish, or preparation of the manuscript.

Competing Interests: The authors have declared that no competing interests exist.

*E-mail: maria.foti@unimib.it

9 These authors contributed equally to this work.

\section{Introduction}

Dendritic cells (DCs) are bone marrow-derived cells present in all lymphoid and non lymphoid organs. They play a role in immune regulation, inducing tolerance and preventing autoimmunity, inducing anti-tumor immunity and protecting against infectious agents. DCs constitute a heterogeneous group of cells with different origins (both myeloid and lymphoid), anatomic locations, cell surface phenotypes and functions. Within the different DCs subtypes, myeloid DCs are also the most efficient antigen-presenting cells in the induction of naive, memory, effector and regulatory $\mathrm{T}$-cell responses [1-3].

DGs have several pattern recognition receptors (such as Tolllike receptors). During infection or inflammation, these receptors interact with microbe-associated molecules (such as LPS, bacterial DNA and double-stranded RNA), resulting in DC activation [4,5]. Endogenous TLR ligands are also released in conditions of inflammation, such as cell injury, and induce similar activation programs [6,7]. These programs affect various DC functions, such as migration to draining lymph nodes for antigen presentation, costimulation and the production of a specific cytokine profile determining the type of $\mathrm{T}$-cell response to be developed. This process is known as maturation and it enables DCs to initiate and direct the acquired immune system (B and $\mathrm{T}$ cells) and, ultimately, to mount an antigen $(\mathrm{Ag})$-specific response [8].

Global transcriptomic analysis has recently been shown to be a powerful approach yielding new insight into the biology of specific cell subsets or tissues, by providing information about their specific gene expression programs [9-12]. Moreover, the analysis of genome-wide expression profiles is now a widely used technique for the identification of diagnostic markers of various disease states, outcomes, or responses to treatment [13-17]. Markers are selected by scoring each individual gene on the basis of the extent to which its expression pattern discriminates between different classes of disease or between cases and controls. The disease status of new patients is predicted with classifiers tuned to the expression levels of the marker genes. One potential problem with expression-based classification is that cellular heterogeneity within tissues and genetic heterogeneity between samples may decrease the discriminatory power of individual genes in complex diseases [18,19]. As DCs are involved in various diseases involving the immune system, from inflammatory diseases to cancer, the identification of molecular markers in DCs specific to inflammation is of potential clinical and pharmaceutical value.

A number of time course and end points studies of the DCs activation process have been published to describe the dynamic process of interaction among gene transcripts that are important for controlling many of the observed changes that occur during the process of activation/maturation [20-28]; however, these studies utilize analysis methods for differential gene expression and do not take into account class prediction methods. We applied a classification algorithm to derive a list of genes able to predict the DCs activation state. In this study, we identified a genetic signature of inflammation in mouse DCs. We chose to study mice, because they are widely used in models of many immunological diseases. These findings may lead to the identification of a 
prospective signature of inflammation and should increase our understanding of the biological processes underlying chronic inflammatory diseases.

\section{Results}

\section{Sample Selection and Processing}

In total, 115 samples were analyzed to develop a prognostic molecular assay of DC activation. Seventy-seven arrays were used for the training set and 38 were used for the testing set. We analyzed different samples of the DG line D1 [29] treated with inflammatory stimuli including bacteria (Listeria monocytogenes), helminths (Schistosoma eggs), protozoa (Leishmania promastigotes) and TLR ligands (LPS, poly I:C and zymosan) and samples of D1 cells treated with dexamethasone, Schistosoma SLA and Leishmania amastigotes, all of which are known to downregulate the inflammatory response [30,31]. The microarray data used were either generated in this study or derived from previous experiments $[23,30,32]$. Table 1 describes the sample dataset used in this study. We amplified total RNA and hybridized it to an Affymetrix mouse MG-U74Av2 GeneChip oligonucleotide microarray containing 12,488 probe sets. The resulting microarray signal intensities for all 12,488 probe sets were normalized and the background was subtracted.

\section{Multivariate Analysis Reveals the Existence of an Inflammatory State for Dendritic Cells}

Principal component analysis (PCA) makes it possible to visualize correlations in datasets by compressing information into a small number of dimensions. PCA was carried out on the data for DCs treated with stimuli inducing activation via various receptors, including the Toll-like receptors. Projection of the samples onto a plane corresponding to the first two dimensions derived from PCA resulted in a clear separation along the first dimension (Figure 1). Control and experimental samples treated with anti-inflammatory stimuli were projected toward positive values of the first dimension and samples with signs of activation were projected toward negative values. The PCA data suggest that DCs in different functional states could be separated on the bases of differences in inflammatory stimulation and that the inflamed

Table 1. Characteristic of the Microarray Data Set used.

\begin{tabular}{llll}
\hline & & & \\
\hline Cell Type & Stimulus & $\mathbf{N}^{\circ}$ of Arrays & Class Ass \\
\hline DC D1 & None & 14 & Non Inflamm \\
DC D1 & DEX & 6 & Non Inflamm \\
DC D1 & Leishmania Ama & 8 & Non Inflamm \\
DC D1 & Shistosoma SLA & 8 & Non Inflamm \\
DC D1 & CpG & 10 & Inflamm \\
DC D1 & Leishmania Pro & 8 & Inflamm \\
DC D1 & Listeria EGD & 20 & Inflamm \\
DC D1 & LPS & 8 & Inflamm \\
DC D1 & PAM3Cys & 10 & Inflamm \\
DC D1 & Poly I:C & 10 & Inflamm \\
DC D1 & Shistosoma Eggs & 8 & Inflamm \\
DC D1 & Zymosan & 15 & Inflamm \\
Total & & 115 & \\
\hline doi:10.1371/journal.pone.0009404.t001 & &
\end{tabular}

samples could be isolated from all the other stimuli in a typical two-classes partitioning.

\section{Data Analysis Strategy for the Selection of Classifier Genes}

We carried out a step-wise analysis to determine whether it was possible to select a gene expression signature of inflammation: (a) an expression index was calculated with RMA [33]; (b) sample classification: genes capable of discriminating between the two groups were identified by comparing groups of samples in the inflammatory group with those in the non inflammatory group (training set); (c) independent validation of classifier genes: the genes selected were used to classify an independent group of samples (testing set); (d) validation of the genetic signature by quantitative RT-PGR (qRT-PGR) on independent DCs samples prepared with different stimuli. The procedure used for the selection and preparation of microarrays is shown in Figure S1.

\section{Transcriptional Signatures Discriminate between Inflammatory and Steady State Cellular Phenotypes}

Raw intensity values from microarray hybridization were normalized with the robust multiarray average in the R-package for statistical computing (available at www.R-project.org). A random forest classification model was built from a training set (50 observations in conditions of inflammation, 27 observations in non inflammatory conditions) obtained from the genome-wide gene expression analysis of DCs incubated with different stimuli. All the samples were assigned to training or testing sets: two thirds of the samples $(n=77)$ were assigned to the training sets, the remaining third being assigned to testing sets $(n=38$; Figure $\mathrm{S} 1)$. The results obtained for the untreated samples and those treated with non inflammatory stimuli were very similar and these two groups of samples were therefore considered to belong to the same class (data not shown). This approach resulted in the identification of 54 genes distinguishing accurately between the two classes of samples, as demonstrated by analysis with the testing set (data not shown; Table 2). The molecular signature was illustrated with a heat map based on Euclidean distance (Figure 2). We identified 18 genes downregulated by inflammation and 36 upregulated by inflammation. Unsupervised clustering analysis confirmed the robustness of the set of genes identified, with very clear distinction between samples treated with and without inflammatory stimuli (Figure 2). Gene Ontology was used to classify the modulated genes in terms of function. The genes selected encoded proteins involved mainly in the immune system process $(44 \%)$, cell differentiation (44\%), cell death $(30 \%)$, and regulation of biological process $(55 \%)$, as shown in Table 3.

The downregulated genes were found to encode proteins involved in the biological pathways of cell division (Gcnb2, Kif20a, Cdc20), lipid metabolic process (Daglb, Elovl6, Lta4h, Sgppl), defense response (hdac5, Illrl1, Il18r1, Lta4h), and metabolic processes (Txndc16, Hdac5, Illrl1, Daglb, Lta4h, Tep1, Sgpp1, H2-DMa, Eif4ebp2, Man2b1, Elovl6, Znrf2, Cdc20). Two of these genes, Tm7sf3 and Tspan8, could not be functionally classified (Table 4). The upregulated genes encoded proteins involved in the immune system response (Psme2, Cd40, Ccl22, Il1b, Sqstm1, Tap1, Il6, Il12b, Ifit1, Ccr7, Irfo, Isg15, Nfkbia, Nfkb1, Stat5a, Cdknla), cell death (Traf1, Stat5a, Sqstm1, Il6, Nfkb1, Cd40, Gdknla, Gadd45b, Tnfrsflb, Serpinb9, Daxx), regulation of biological processes (Nfkbia, Trafl, Stat5a, Illb, Clic4, Nfkbiz, Icam1, Gadd45b, Il12b, Irf8, Tnfrsflb, Serpinb9, Dnajb6, Sqstm1, Il6, Nfkbl, Cd40, Cdknla, Daxx, Gnai3,) and cell differentiation (Nfkbia, Skil, Trafl, Stat5a, Clic4, Gadd45b, 


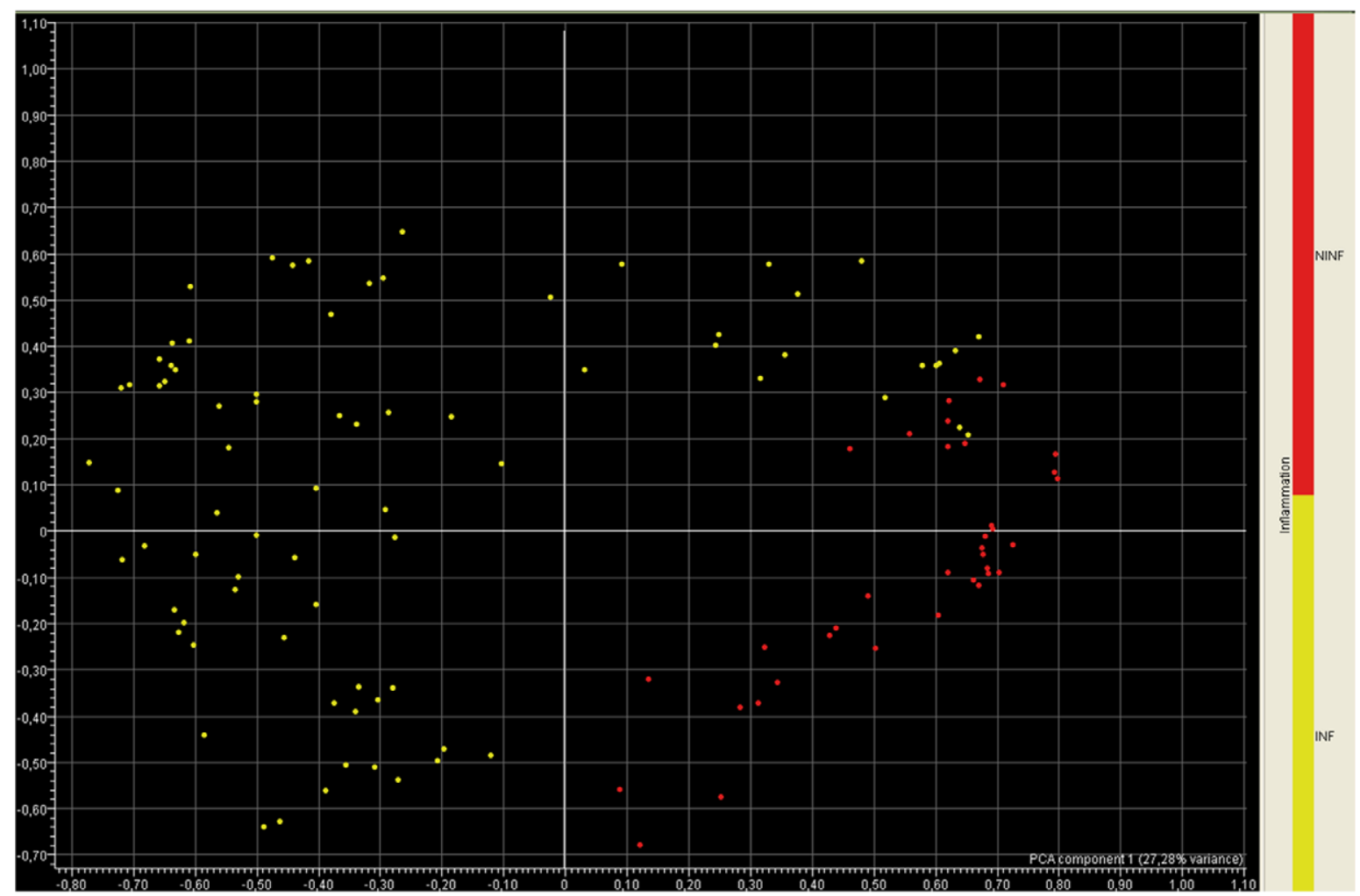

Figure 1. PCA score plot. Seventy-nine "inflammatory" observations and 36 "non inflammatory" observations (listed in Table 1) used to generate and test the random forest model. Genome-wide gene expression data were collected with DNA-microarray technology and the normalized hybridization signals were analyzed by PCA. A score plot with the first and second principal component axes is shown. Inflamed samples are mostly projected toward negative values of the first PC axis, whereas samples from controls and non inflamed samples are projected toward positive values. INF: Inflamed samples; NINF: non-inflamed samples. doi:10.1371/journal.pone.0009404.g001

Il12b, Irf8, Tnfrsflb, Serpinb9, Sqstm1, Il6, Nfkb1, Cd40, Cdknla, Daxx).

\section{Real-Time Reverse Transcriptase (RT)-PCR Validation of Microarray Observations}

Despite the accuracy of the classifier for random forest-based class assignment in a test set of DC samples, the mean expression index of transcripts was low. We therefore performed qRT-PCR to confirm the relative expression levels recorded for the DC samples with Affymetrix technology. We used the 18s rRNA gene as a housekeeping gene for the normalization of target gene expression. We prepared independent DC line D1 samples by treating the cells for $24 \mathrm{~h}$ with known signals, such as $10 \mu \mathrm{g} / \mathrm{ml}$ LPS, $20 \mu \mathrm{g} / \mathrm{ml}$ Poly I:C and $500 \mathrm{ng} / \mathrm{ml}$ zymosan, and with $10^{-8} \mathrm{M}$ dexamethasone, $10^{-8} \mathrm{M}$ vitamin $\mathrm{D}$ and $50 \mathrm{ng} / \mathrm{ml}$ IL10, which are known to have anti-inflammatory activity [34-38]. All the RNA samples in the study were converted to cDNA using the same reverse-transcription cocktail and procedure. The pattern of gene expression observed on qRT-PCR confirmed the microarray data. We assessed the predictive value of genes by calculating the median levels of expression for that gene in the known inflammatory and anti-inflammatory samples and then determining the mean expression level for the gene between the two classes. These threshold values were used to determine whether, for a given stimulus, the level of expression of the gene could be used to assign the sample to the correct class. We therefore subjected all the genes to the same test, under different stimulation conditions. A score of 1 was assigned if the expression level exceeded the mean expression value for an upregulated gene for a sample to be inflammatory or was less than the mean value for a sample to be anti-inflammatory. For repressed genes, we applied the opposite, a score of 1 was assigned if the expression level was less than the mean expression value for a sample to be inflammatory or was more than the mean value for a sample to be anti-inflammatory. A score of 0 was awarded in all other cases (Figure S2). Poly I:C stimulation was correctly classified by $94 \%(51 / 54)$ of the genes, whereas LPS and zymosan stimulations were correctly classified by $89 \%(48 / 54)$ and $85 \%(46 / 54)$ of the genes, respectively. As predicted, dexamethasone was the best anti-inflammatory reagent, correctly classified by $100 \%(54 / 54)$ of the genes. IL10 and vitamin $\mathrm{D}$ were identified as anti-inflammatory stimuli by $96 \%$ $(52 / 54)$ and $89 \%(48 / 54)$ of the genes, respectively (Figure 3).

Vitamin D upregulated Illb, Rab20, Nfkbia, Nfkbiz and Skil. These genes are upregulated by TLRs ligands (Figure 3). The effect of vitamin D on IL-1b gene expression has already been demonstrated in primary mouse keratinocytes and other cell types, whereas the induction of proteins involved in intracellular trafficking has not previously been shown [39,40-42]. Rab20 was recently identified as a potential regulator of connexin 43 trafficking [43].

We then assessed the power of the selected genetic signatures to classify samples treated with different reagents probing different types of receptors. We treated DCs with live bacteria, such as Listeria monocytogenes and Lactobacillus paracasei, $10 \mu \mathrm{M}$ nimesulide and $1000 \mathrm{U} / \mathrm{ml} \mathrm{IFN} \alpha$ to modify their functional state. As expected, live bacteria induced the strongest inflammatory 
Table 2. Fifty-four Genes able to predict Inflammatory Signatures in DC.

\begin{tabular}{|c|c|c|}
\hline Affymetrix ID & Gene Title & Gene Symbol \\
\hline 100423_f_at & SIGNAL TRANSDUCER AND ACTIVATOR OF TRANSCRIPTION 5A & STAT5A \\
\hline 100540_at & LEUKOTRIENE A4 HYDROLASE & LTA4H \\
\hline 100584_at & ANNEXIN A4 & ANXA4 \\
\hline 100588_at & PROTEASOME (PROSOME, MACROPAIN) 28 SUBUNIT, BETA & PSME2 \\
\hline 100779_at & INTERLEUKIN 12B & IL12B \\
\hline 100981_at & INTERFERON-INDUCED PROTEIN WITH TETRATRICOPEPTIDE REPEATS 1 & IFIT1 \\
\hline 101072_at & EUKARYOTIC TRANSLATION INITIATION FACTOR 4E BINDING PROTEIN 2 & EIF4EBP2 \\
\hline 101144_at & INTERLEUKIN 18 RECEPTOR 1 & IL18R1 \\
\hline 101995_at & SEQUESTOSOME 1 & SQSTM1 \\
\hline 102218_at & INTERLEUKIN 6 & IL6 \\
\hline 102310_at & CHEMOKINE (C-C MOTIF) LIGAND 22 & CCL22 \\
\hline 102779_at & GROWTH ARREST AND DNA-DAMAGE-INDUCIBLE 45 BETA & GADD45B \\
\hline 102831_s_at & CD86 ANTIGEN & CD86 \\
\hline 103035_at & TRANSPORTER 1, ATP-BINDING CASSETTE, SUB-FAMILY B (MDR/TAP) & TAP1 \\
\hline 103040_at & CD83 ANTIGEN & CD83 \\
\hline 103254_at & TRAF TYPE ZINC FINGER DOMAIN CONTAINING 1 & TRAFD1 \\
\hline 103402_at & TRANSMEMBRANE 7 SUPERFAMILY MEMBER 3 & TM7SF3 \\
\hline 103486_at & INTERLEUKIN 1 BETA & IL1B \\
\hline 103494_at & TETRASPANIN 8 & TSPAN8 \\
\hline 103665_at & ELOVL FAMILY MEMBER 6, ELONGATION OF LONG CHAIN FATTY ACIDS (YEAST) & ELOVL6 \\
\hline 104149_at & NUCLEAR FACTOR OF KAPPA LIGHT CHAIN GENE ENHANCER IN B-CELLS INHIBITOR, ALPHA & NFKBIA \\
\hline 104376_at & HISTONE DEACETYLASE 5 & HDAC5 \\
\hline 104418_at & ZINC AND RING FINGER 2 & ZNRF2 \\
\hline 104443_at & CHEMOKINE (C-C MOTIF) RECEPTOR 7 & CCR7 \\
\hline 160501_at & KINESIN FAMILY MEMBER 20A & KIF20A \\
\hline 160608_at & RAB20, MEMBER RAS ONCOGENE FAMILY & RAB20 \\
\hline 161005_at & RIKEN CDNA 5730420B22 GENE & TXNDC16 \\
\hline 92962_at & CD40 ANTIGEN & CD40 \\
\hline 93092_at & HISTOCOMPATIBILITY 2, CLASS II, LOCUS DMA & H2-DMA \\
\hline 93367_at & TELOMERASE ASSOCIATED PROTEIN 1 & TEP1 \\
\hline 93448_at & RIKEN CDNA E330036119 GENE & DAGLB \\
\hline 94186_at & TNF RECEPTOR-ASSOCIATED FACTOR 1 & TRAF1 \\
\hline 94256_at & CHLORIDE INTRACELLULAR CHANNEL 4 (MITOCHONDRIAL) & CLIC4 \\
\hline 94294_at & CYCLIN B2 & CCNB2 \\
\hline 94501_at & SPHINGOSINE-1-PHOSPHATE PHOSPHATASE 1 & SGPP1 \\
\hline 94752_s_at & SKI-LIKE & SKIL \\
\hline 94814_at & GUANINE NUCLEOTIDE BINDING PROTEIN, ALPHA INHIBITING 3 & GNAI3 \\
\hline 94881_at & CYCLIN-DEPENDENT KINASE INHIBITOR 1A (P21) & CDKN1A \\
\hline 94928_at & TUMOR NECROSIS FACTOR RECEPTOR SUPERFAMILY, MEMBER 1B & TNFRSF1B \\
\hline 95024_at & UBIQUITIN SPECIFIC PEPTIDASE 18 & USP18 \\
\hline 96120_at & DNAJ (HSP40) HOMOLOG, SUBFAMILY B, MEMBER 6 & DNAJB6 \\
\hline 96125_at & FAS DEATH DOMAIN-ASSOCIATED PROTEIN & DAXX \\
\hline 96319_at & RIKEN CDNA 2310042N09 GENE & $\mathrm{CDC} 20$ \\
\hline 96515_at & INTERLEUKIN 4 INDUCED 1 & IL4I1 \\
\hline 96752_at & INTERCELLULAR ADHESION MOLECULE & ICAM1 \\
\hline 96935_at & PDZK1 INTERACTING PROTEIN 1 & PDZK1IP1 \\
\hline 98002_at & INTERFERON REGULATORY FACTOR 8 & IRF8 \\
\hline 98405_at & SERINE (OR CYSTEINE) PEPTIDASE INHIBITOR, CLADE B, MEMBER 9 & SERPINB9 \\
\hline 98427_s_at & NUCLEAR FACTOR OF KAPPA LIGHT CHAIN GENE ENHANCER IN B-CELLS 1, P105 & NFKB1 \\
\hline 98500_at & INTERLEUKIN 1 RECEPTOR-LIKE 1 & IL1RL1 \\
\hline
\end{tabular}


Table 2. Cont.

\begin{tabular}{lll}
\hline & & \\
\hline Affymetrix ID & Gene Title & Gene Symbol \\
\hline 98822 at & INTERFERON, ALPHA-INDUCIBLE PROTEIN & ISG15 \\
98988_at & NUCLEAR FACTOR OF KAPPA LIGHT POLYPEPTIDE GENE ENHANCER IN B-CELLS INHIBITOR, ZETA & NFKBIZ \\
99562 at & MANNOSIDASE 2, ALPHA B1 & MAN2B1 \\
99982 at & NUCLEAR FACTOR OF KAPPA LIGHT CHAIN GENE ENHANCER IN B-CELLS INHIBITOR, BETA & NFKBIB \\
\hline
\end{tabular}

doi:10.1371/journal.pone.0009404.t002

signature response in DCs (Figure 4A): Listeria monocytogenes and Lactobacillus paracasei were correctly classified as inflammatory by 98\% (53/54) and 94\% (51/54) of the genes, respectively. Listeria monocytogenes is known to induce the production of type I IFNs. We therefore expected this bacterium to induce the interferonresponsive genes Ifitl and Isg15. Levels of transcription for Illb, Pdzklip1, Isg15, Ifit l and Usp18 were strongly reduced by Lactobacillus paracasei. We therefore conclude that Lactobacillus paracasei is less able to induce a type I IFN response than other genes of the inflammatory signature, suggesting that commensal bacteria may specifically modulate inflammatory genes in DCs (Figure 4A). Finally, we measured the effect of IFN $\alpha$ and nimesulide treatment on DCs. We compared the results obtained with nimesulide and IFN $\alpha$ with the signatures obtained with dexamethasone, IL10 and vitamin D (Figure 4B). Nimesulide and IFN $\alpha$ were classified as anti-inflammatory by $98 \%(53 / 54)$ and $80 \%(43 / 54)$ of the genes, respectively. Isg15, Ifit1, Usp18 are known to be regulated by IFN $\alpha$, whereas Clic4, Trafd1 and Il4il

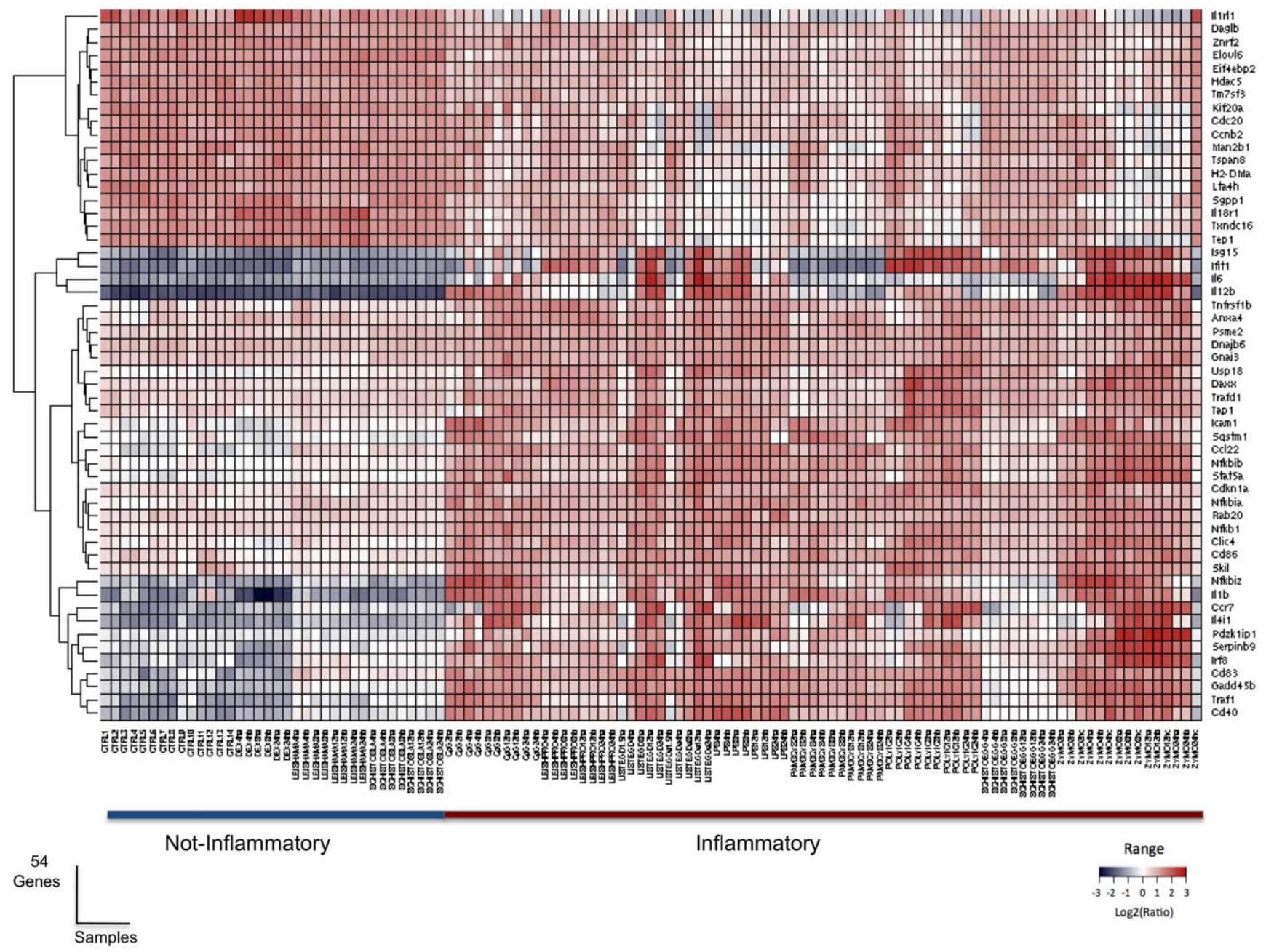

Figure 2. Heat map of the dendritic cell-specific signature. Genes with different levels of expression in DCs treated with inflammatory stimuli and in those treated with anti-inflammatory molecules. Each column represents a sample and each row represents a gene. Levels of gene expression are indicated on a color scale, with red corresponding to the highest level of expression and blue corresponding to the lowest level. The Log 2 ratio is expressed with respect to the mean expression level of each gene.

doi:10.1371/journal.pone.0009404.g002 
Table 3. Upregulated genes are grouped functionally based on ontologies, and levels of significance are shown.

\begin{tabular}{|c|c|c|c|c|c|c|}
\hline GO Biological Process & N. of Genes & $\%$ & pValue & Gene symbol & Benjamini & FDR \\
\hline GO:0002376-immune system process & 16 & 44,44 & $2,69 \mathrm{E}-11$ & $\begin{array}{l}\text { Psme2, Nfkbia, Stat5a, IL1b, Tap1, } \\
\text { IL12b, Irf8, Ccl22, Sastm1, Il6, Nfkb1, } \\
\text { CD40, Cdkn1a, Ifit1, Ccr7, Isg15 }\end{array}$ & $1,39 \mathrm{E}-07$ & $5,13 \mathrm{E}-08$ \\
\hline GO:0030154- cell differentiation & 16 & 44,44 & $9,5 \mathrm{E}-07$ & $\begin{array}{l}\text { Nfkbia, Skil, Traf1, Stat5a, Clic4, } \\
\text { Gadd45b, Il12b, Irf8, Tnfrsf1b, } \\
\text { Serpinb9, Sqstm1, II6, Nfkb1, } \\
\text { Cd40, Cdkn1a, Daxx }\end{array}$ & $1,23 \mathrm{E}-03$ & $1,82 \mathrm{E}-03$ \\
\hline GO:0008219- cell death & 11 & 30,56 & 1,16E-06 & $\begin{array}{l}\text { Traf1, Stat5a, Sqstm1, Il6, Nfkb1, } \\
\text { Cd40, Cdkn1a, Gadd45b, Tnfrsf1b, } \\
\text { Serpinb9, Daxx }\end{array}$ & 1,21E-03 & $2,23 \mathrm{E}-03$ \\
\hline GO:0001816-cytokine production & 6 & 16,67 & 3,86E-06 & Stat5a, $\|1 b\| 6$, Nfkb1, Cd40, $\| 12 b$ & $2,86 \mathrm{E}-03$ & $7,37 \mathrm{E}-03$ \\
\hline GO:0012501- programmed cell death & 10 & 27,78 & 7,97E-06 & $\begin{array}{l}\text { Traf1, Stat5a, Sqstm1, Il6, Nfkb1, } \\
\text { Cd40, Cdkn1a, Gadd45b, } \\
\text { Serpinb9, Daxx }\end{array}$ & 4,59E-03 & $1,52 \mathrm{E}-02$ \\
\hline GO:0006954- inflammatory response & 6 & 16,67 & 9,43E-05 & Ccl22, Stat5a, Il1b, Il6, Nfkbiz, Tnfrsf1b & $3,01 \mathrm{E}-02$ & $1,80 \mathrm{E}-01$ \\
\hline GO:0032502- developmental process & 17 & 47,22 & 9,91E-05 & $\begin{array}{l}\text { Nfkbia, Skil, Traf1, Stat5a, Clic4, } \\
\text { Anxa4, Gadd45b, II12b, Irf8, } \\
\text { Tnfrsf1b, Serpinb9, Sqstm1, Il6, } \\
\text { Nfkb1, Cd40, Cdkn1a, Daxx, }\end{array}$ & $2,98 \mathrm{E}-02$ & $1,89 \mathrm{E}-01$ \\
\hline $\begin{array}{l}\text { GO:0050789- regulation of } \\
\text { biological process }\end{array}$ & 20 & 55,56 & $1,13 \mathrm{E}-04$ & $\begin{array}{l}\text { Nfkbia, Traf1, Stat5a, II1b, Clic4, } \\
\text { Nfkbiz, Icam1, Gadd45b, II12b, } \\
\text { Irf8, Tnfrsf1b, Serpinb9, Dnajb6, } \\
\text { Sqstm1, Il6, Nfkb1, Cd40, } \\
\text { Cdkn1a, Daxx, Gnai3 }\end{array}$ & $3,21 \mathrm{E}-02$ & $2,16 \mathrm{E}-01$ \\
\hline GO:0050896- response to stimulus & 17 & 47,22 & 4,73E-04 & $\begin{array}{l}\text { Nfkbia, Stat5a, II1b, Nfkbiz, } \\
\text { Tap1, II12b, Irf8, Tnfrsf1b, } \\
\text { Ccl22, Sqstm1, Il6, Cd86, Cd40, } \\
\text { Cdkn1a, Ifit1, Ccr7, Isg15 }\end{array}$ & 7,87E-02 & $9,01 \mathrm{E}-01$ \\
\hline GO:0032020- ISG15 protein conjugation & 2 & 5,56 & $1,03 \mathrm{E}-02$ & Usp18, Isg15 & $5,69 \mathrm{E}-01$ & $1,80 \mathrm{E}+01$ \\
\hline GO:0007154-cell communication & 16 & 44,44 & $1,49 \mathrm{E}-02$ & $\begin{array}{l}\text { Nfkbia, Traf1, Stat5a, II1b, Rab20, } \\
\text { Gadd45b, I12b, Tnfrsf1b, Ccl22, } \\
\text { Sqstm1, II6, Nfkb1, Cd40, Ccr7, } \\
\text { Daxx, Gnai3 }\end{array}$ & $6,86 \mathrm{E}-01$ & $2,49 \mathrm{E}+01$ \\
\hline
\end{tabular}

doi:10.1371/journal.pone.0009404.t003

have not been shown to be affected by IFN $\alpha$. This confirms the role of IFN $\alpha$ in the regulation of DC activity [44,45].

We were able to classify samples treated with IFN $\alpha$, Il10, vitamin $\mathrm{D}$ as non inflammatory with this system, whereas live bacteria (Listeria and Lactobacillus) were classified as inflammatory on the basis of the strong inflammatory signatures induced. LPS and Poly I:C were found to be stronger inducers of DC activation than zymosan (46/54), at least in our experimental conditions. Zymosan has also been shown to induce a regulatory phenotype in DCs [46].
Transcription Signatures Are Dendritic Cell-Specific

We assessed the specificity of the classifier genes by analyzing 44 of the 54 genes that gave consistent results for different samples by qRT-PGR, in the macrophage cell line MT2 [47]. The MT2 cells were stimulated with $10^{-8} \mathrm{M}$ dexamethasone or $10 \mu \mathrm{g} / \mathrm{ml} \mathrm{LPS}$. The genes of the inflammation signature were not well expressed in MT2 cells if compared to the D1 cells (Figure 5). Only $41 \%$ $(18 / 44)$ of the genes showed the expected pattern of change in expression in response to LPS stimulation in MT2 cells. Indeed,

Table 4. Downregulated genes are grouped functionally based on ontologies.

\begin{tabular}{|c|c|c|c|c|c|c|}
\hline GO Biological Process & N. of Genes & $\%$ & pValue & Gene symbol & Benjamini & FDR \\
\hline GO:0051301- cell division & 3 & 16,67 & $2,45 \mathrm{E}-02$ & Ccnb2, Kif20a, Cdc20 & 1 & 37,754 \\
\hline GO:0006629- lipid metabolic process & 4 & 22,22 & $2,57 \mathrm{E}-02$ & Daglb, Elovl6, Lta4h, Sgpp1 & 1 & 39,157 \\
\hline GO:defense response & 4 & 22,22 & $3,36 \mathrm{E}-02$ & Hdac5, II1rl1, II18r1, Lta4h & 1 & 47,956 \\
\hline GO:0008152- metabolic process & 13 & 72,22 & $3,38 \mathrm{E}-02$ & $\begin{array}{l}\text { Txndc16, Hdac5, II1rl1, Daglb6, Lta4h, } \\
\text { Tep1, Sgpp1, H2-DMa, Eif4ebp2, } \\
\text { Man2b1, Elovl6, Znrf2, Cdc20 }\end{array}$ & 1 & 48,194 \\
\hline GO:0002376- immune system process & 4 & 22,22 & $5,10 \mathrm{E}-02$ & Hdac5, H2-DMa, II1rl1, I/18r1 & 1 & 63,237 \\
\hline GO:0045087- innate immune response & 2 & 11,11 & $9,56 \mathrm{E}-02$ & $\|1 \mathrm{rl1}\| ,18 \mathrm{r} 1$ & 1 & 85,352 \\
\hline
\end{tabular}




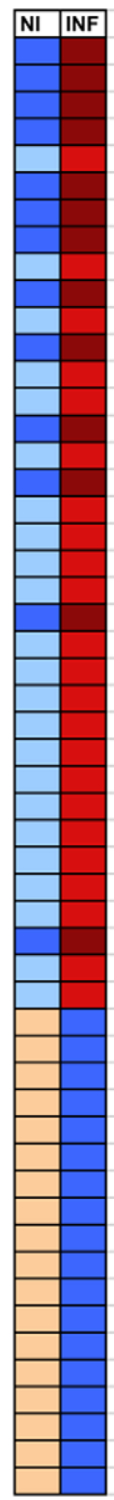

\begin{tabular}{|c|c|c|c|c|c|c|}
\hline Gene Name & DEX & VitD & $\mathrm{IL}-10$ & LPS & poly I:C & ZymA \\
\hline IL-6 & 0,61 & 1,02 & 0,91 & & 10,83 & \\
\hline IL12B & & 0,87 & 0,62 & 139,32 & 28,66 & 306,94 \\
\hline PDZK1lp1 & 0,98 & 0,38 & & 32.59 & 1,02 & 11,91 \\
\hline IL-4l1 & 0,43 & 0,74 & 0,54 & 20,73 & 36,38 & 19,89 \\
\hline CCL22 & 0,18 & 0,33 & 0,42 & 16,14 & 17,23 & 7,76 \\
\hline CD83 & 0,50 & 0,32 & 0,53 & 16,06 & 23,28 & 7,31 \\
\hline GADD45B & 0,80 & 0,73 & 0,84 & 14,90 & 20,20 & 7,76 \\
\hline IL1B & & 11,02 & 1,58 & 14,57 & 6,54 & 9,72 \\
\hline CD40 & 0,53 & 0,54 & 0,66 & 13,10 & 15,04 & 6,22 \\
\hline NFKBIZ & 0,72 & 1,75 & 1,19 & 12,25 & 1,94 & 2,02 \\
\hline RAB20 & 0.48 & 4,19 & 1,22 & 11,52 & 9,96 & 5,03 \\
\hline CCR7 & 0,44 & 0.47 & 0,56 & 11,38 & 25,14 & 6,67 \\
\hline TRAF1 & 0,57 & 0,94 & 1,09 & 10,15 & 14,88 & 6,85 \\
\hline STAT5A & 0,88 & 0,71 & 0,75 & 7,38 & 6,37 & 3,53 \\
\hline ISG15 & 0,31 & 0,96 & 0,74 & 5,07 & 17,46 & 7,30 \\
\hline NFKBIA & 0,77 & 1,95 & 1,01 & 4,48 & 3,83 & 3,85 \\
\hline IRF8 & & 0,83 & 0,67 & 3,92 & 11,21 & 4,22 \\
\hline ICAM1 & 0,95 & 1,02 & 0,86 & 3,83 & 4,74 & 3,21 \\
\hline NFKBIB & 0.55 & 0,55 & 0.52 & 3,38 & 3,30 & 2,15 \\
\hline TNFRSF1B & 0.58 & 0.60 & 0,70 & 2,51 & 3,05 & 1,60 \\
\hline SQTM1 & 0,94 & 1,07 & 0,87 & 2,16 & 3,53 & 2,43 \\
\hline IFIT1 & 0,47 & 1,46 & 0,86 & 2,08 & 17,57 & 5,91 \\
\hline SKIL & 0,76 & 1,61 & 0,81 & 1,97 & 1,38 & 1,29 \\
\hline GNAl3 & 0,88 & 1,10 & 1,28 & 1,93 & 1,63 & 1,23 \\
\hline USP18 & 0,56 & 0.60 & 0,73 & 1,93 & 3,50 & 1.80 \\
\hline NFKB1 & 0,63 & 0,59 & 0,71 & 1,83 & 1,98 & 1,42 \\
\hline CD86 & 1,12 & 1,16 & 1,52 & 1,69 & 1,75 & 1,64 \\
\hline CLIC4 & 0,79 & 1,00 & 0,99 & 1,55 & 2,25 & 1,33 \\
\hline TAP1 & 0,57 & 1,27 & 0,92 & 1,42 & 3,37 & 2,22 \\
\hline PSME2B-PS & 0,46 & 0,59 & 0,65 & 1,41 & 2,31 & 1,33 \\
\hline ANXA4 & 0,51 & 0,65 & 0,59 & 1,28 & 1,47 & 1,40 \\
\hline DNAJB6 & 0,81 & 1,34 & 1,51 & 1,25 & 2,06 & 1,40 \\
\hline TRAFD1 & 0,64 & 1,19 & 1,14 & 1,16 & 2,69 & 1,84 \\
\hline SERPINB9 & 0,31 & 0,56 & 0,52 & 1,16 & 2,52 & 1,76 \\
\hline CDKN1a & 0,37 & 0,63 & 0,65 & 0,83 & 2,28 & 1,50 \\
\hline DAXX & 0,54 & 0,91 & 0,79 & 0,75 & 1,89 & 1,25 \\
\hline EIF4EBP2 & 0,75 & 0,71 & 0,73 & 0,63 & 0,53 & 0,53 \\
\hline ELOVL6 & 0,86 & 0,64 & 1,03 & 0,61 & 0.29 & 0,56 \\
\hline TM7SF3 & 0,87 & 1,09 & 1,19 & 0,51 & 0,34 & 0,72 \\
\hline TSPAN8 & 2,38 & 0,93 & 1,59 & 0,50 & 0.27 & 0,52 \\
\hline CCNB2 & 1,01 & 0,98 & 0,97 & 0,45 & 0,20 & 0,40 \\
\hline ZNRF2 & 0,82 & 0,77 & 1,10 & 0,45 & 0.26 & 0,71 \\
\hline LTA4H & 0,59 & 0,66 & 0,92 & 0,43 & 0,16 & 0,44 \\
\hline IL18R1 & 1,87 & 1,07 & 0,88 & 0,41 & 0,38 & 0,46 \\
\hline TEP1 & 0,68 & 0,87 & 1,34 & 0,40 & 0,34 & 0,61 \\
\hline HDAC5 & 0,95 & 0,82 & 1,00 & 0,39 & 0,48 & 0,47 \\
\hline KIF20A & 1,22 & 0,76 & 0,72 & 0,36 & 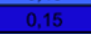 & 0,40 \\
\hline H2-DMa & 1,05 & 1,15 & 0,88 & 0,34 & 0,36 & 0,62 \\
\hline CDC20 & 1,03 & 0,69 & 0,73 & 0,31 & 0,17 & \\
\hline DAGLB & 0,66 & 0,46 & 0,68 & 0.31 & 0.28 & 0,44 \\
\hline TXNDC16 & 1,12 & 1,03 & 1,07 & 0,28 & 0.19 & 0,40 \\
\hline SGPP1 & 1,34 & 0,91 & 0,84 & 0,26 & 0.22 & 0,51 \\
\hline MAN2B1 & 0,93 & 0,95 & 0,83 & 0.22 & 0,19 & 0,40 \\
\hline IL1RL1 & 1,28 & 0,76 & 0,70 & 0.07 & 0,02 & 0,13 \\
\hline
\end{tabular}

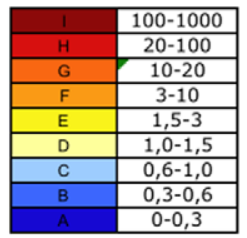

Figure 3. Sample validation by quantitative real-time PCR. qRT-PCR confirmation of classifier transcript levels in inflamed samples derived from DCs treated with TLR ligands (LPS, Polyl:C and zymosan) and in non inflamed samples treated with anti-inflammatory stimuli (dexamethasone, vitamin D and IL-10) for $24 \mathrm{~h}$. Reactions were performed in two wells, normalized to $18 \mathrm{~s}$ rRNA levels. The results in the table are expressed relative to the corresponding level of expression of each transcript in the untreated sample. Data are presented as mean fold changes in classifier gene transcript levels in three independent experiments per group. The columns in the left reflect the pattern of expression as determined by microarray analysis. NI: Non inflamed samples; INF; Inflamed samples. doi:10.1371/journal.pone.0009404.g003

some genes displayed opposite patterns of expression in the two cell lines tested. Il18r1 was induced in MT2 cells but downregulated in DCs in response to LPS. We therefore conclude that the inflammatory signature identified in this study is specific to DCs.

\section{Classifier Genes Can Be Used to Predict the Inflammatory Process in DCs In Vivo}

Preclinical animal models of inflammation and infections have become important tools for improving our understanding of the regulation of inflammatory reactions in general and for the development of novel treatment strategies to modulate excessive, deleterious inflammatory reactions. We measured the gene expression signature associated with inflammation in ex vivo splenic DCs derived from mice treated with the endotoxin LPS, and dexamethasone with the aim of converting our in vitro DC assay into a useful tool for preclinical mouse models of inflammatory diseases.

Splenic DCs detect antigens derived from the blood and are widely used as a model system for testing treatments that affect DC recruitment or for detecting DC activation during systemic infection. We analyzed the pattern of expression of the 44 genes in splenic DCs in vivo. We treated a group of mice with $50 \mu \mathrm{g}$ of LPS/mouse or dexamethasone and, after $5 \mathrm{~h}, \mathrm{CD} 1 \mathrm{lc}^{+}$cells were purified from spleen by magnetic bead separation. Cell purity was checked by FACS analysis and $90 \%$ of the cells were found to be $\mathrm{CD}_{11 \mathrm{c}^{+}}$(data not shown) then assessed the prognostic value of the 44 genes by qRT-PCR: $91 \%(40 / 44)$ and $80 \%$ (35/44) of the genes correctly predicted the inflammatory or non inflammatory 


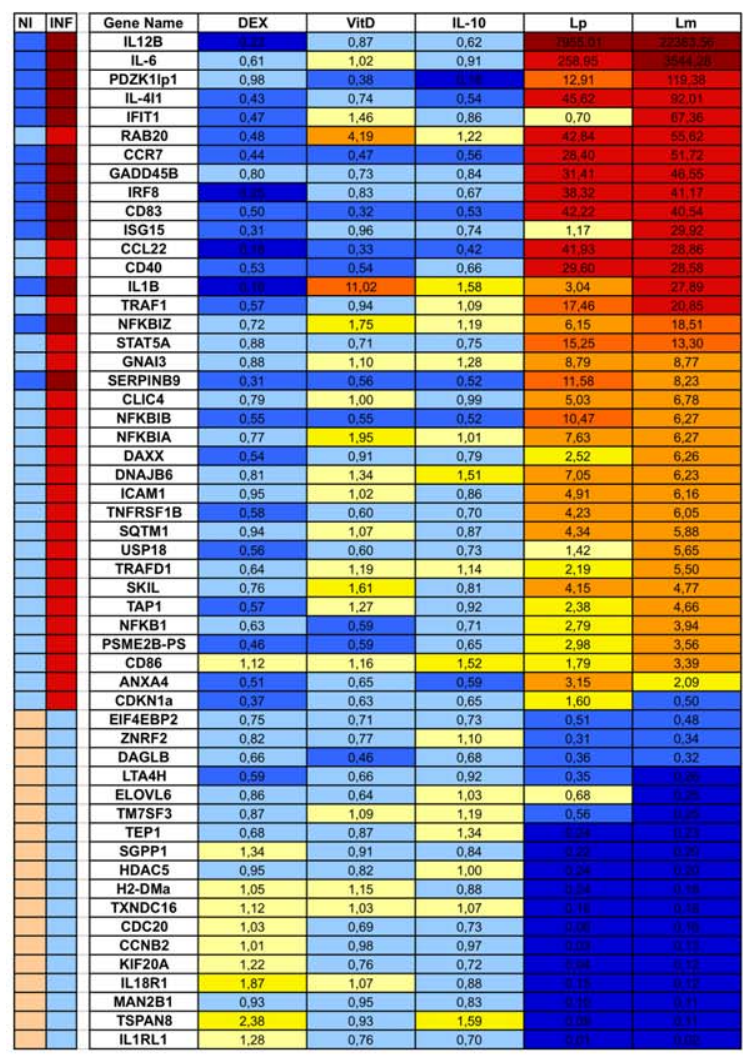

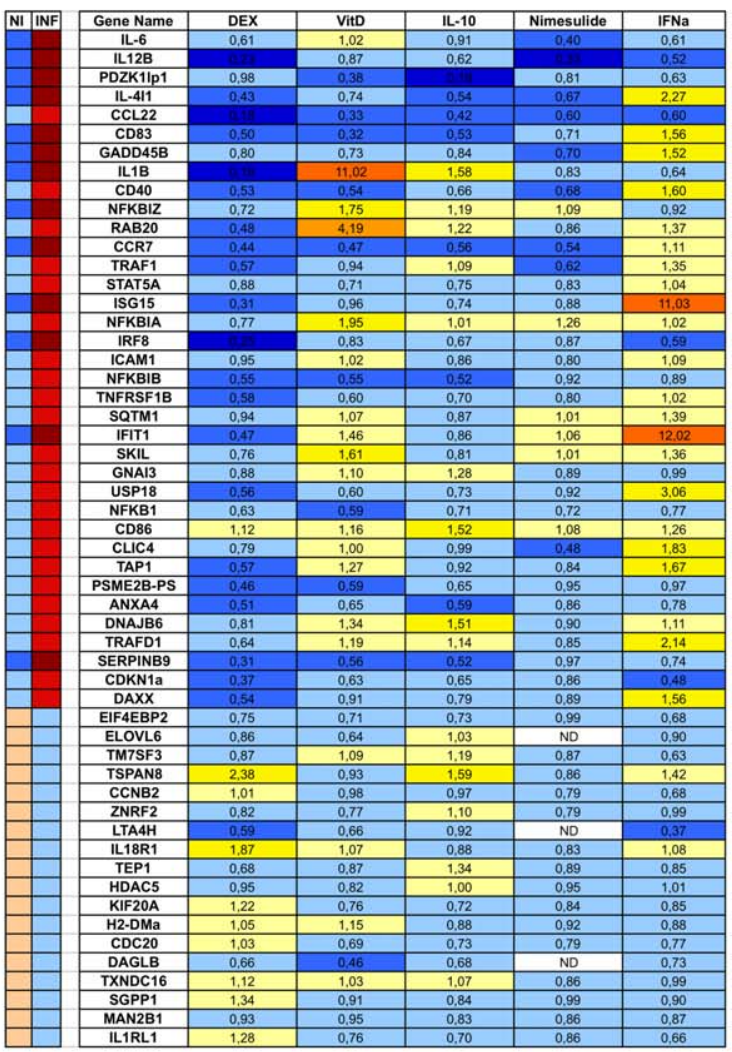

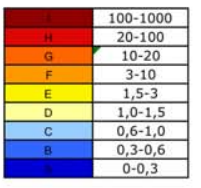

Figure 4. q-Real-time PCR analysis of gene expression on independent samples for class prediction. A) Expression levels of 54 genes in DCs treated with the bacteria Listeria monocytogenes (Lm) and Lactobacillus paracasei (Lp) for $24 \mathrm{~h}$. B) DC samples treated with nimesulide and IFN $\alpha$ for $24 \mathrm{~h}$. Comparison with cells treated with dexamethasone (DEX), IL-10 and vitamin D (VitD). Data are presented as mean fold changes in classifier gene transcript levels in three independent experiments per group. NI: Non inflamed samples; INF; Inflamed samples. doi:10.1371/journal.pone.0009404.g004

phenotype of splenic DCs, confirming that the inflammatory signature selected in this study was also induced in DCs in vivo (Figure 6 and Figure S3). We were unable to confirm the induction of Ill2b, Irfo and Nfkbl by LPS in vivo, possibly due to a lower expression of these genes in vivo.

\section{Discussion}

The development and marketing of microarray platforms has led to extensive investigation of global gene expression profiles in health and disease. The expression profiling of diverse healthy tissues provides a comprehensive view of the range of transcriptional regulation in physiological conditions [43,48-50]. Similarly, the identification of gene expression signatures indicative of disease subtypes improves our understanding of the molecular basis of disease [13,14,51]. Small sample size and the large number of measurements required for each sample currently limit the efficacy of gene expression profiling, leading to efforts to develop new analytical methods. Gene expression profiles have recently found applications in diagnosis, prognosis and the provision of predictive information, and in the classification of human cancers and inflammatory diseases [52,53].

In this study, we used the random forest algorithm [54] to identify specific transcriptional signatures of inflammation in DCs and to evaluate whether these molecular signatures could be used to determine the activation state of DCs in vitro and in vivo. We found that the selected predictive genes upregulated during DGs activation fell into distinct functional classes, with major involvement in immune system processes $(47 \%)$ cell differentiation (44\%), metabolic process $(42 \%)$ and cell death (31\%). Gene Ontology analysis identified the genes involved in immune system processes as Psme2, Cd40, Gcl22, Illb, Sqstm1, Tap1, Il6, Il12b, Ifit1, Ccr7, Irf8, Isg15, Nfkbia, Nfkb1, Stat5a and Cdknla. The genes involved in cell differentiation identified were Nfkbia, Skil, Traf1, Stat5a, Clic4, Gadd45b, Il12b, Irfo, Tnfrsflb, Serpinb9, Sqstm1, Il6, Nfkb1, Cd40, Cdknla and Daxx. Gene Ontology analysis also identified genes involved in cell death, such as Trafl, Stat5a, Sqstm1, Il6, Nfkb1, Cd40, Cdknla, Gadd45b, Tnfrsflb, Serpinb9 and Daxx. The downregulated predictive genes were identified as involved in cell division (Ccnb2, Kif20a, Cdc20), lipid metabolism (Daglb, Elovl6, Lta4h, Sgpp1), defense responses (hdac5, Illrll, Ill8rl, Lta4h) and metabolic processes (Txndc16, Hdac5, Illrll, Daglb, Lta4h, Tep1, Sgpp1, H2-DMa, Eif4ebp2, Man2b1, Elovl6, Znrf2, Cdc20).

Most of the genes selected showed a sustained up-regulation or down-regulation suggesting that the processes they sustain, are important throughout the maturation process. Nevertheless, to deeply understand their functional role during DCs maturation, knock down studies should be performed on one or more genes of the signature.

Our findings clearly demonstrate that the gene expression profiling of DCs reliably distinguishes between activating and non activating stimuli. We validated our findings on an independent set of samples treated with molecules inducing the activity of different 


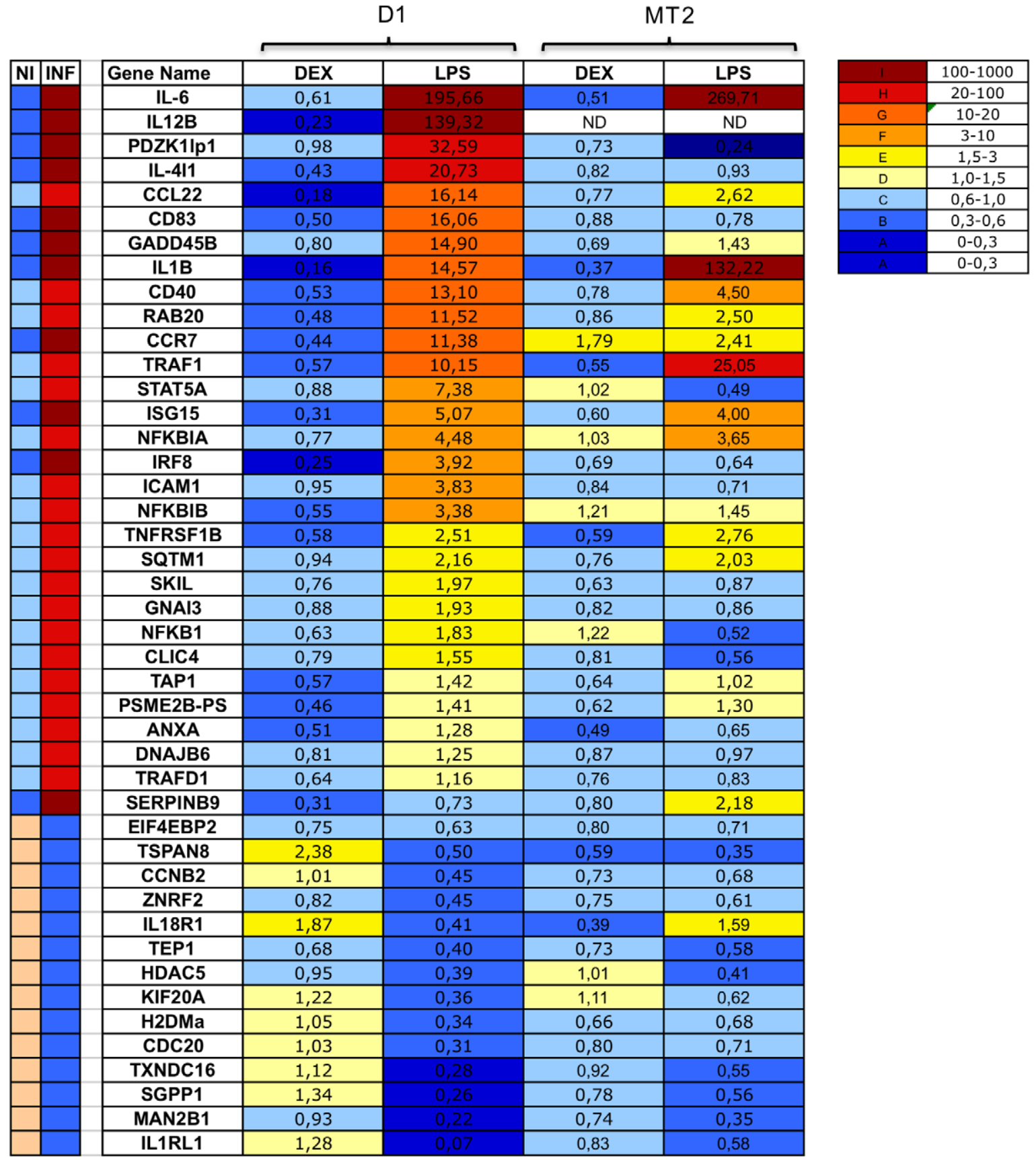

Figure 5. Specificity of the genetic signature. Real-time PCR confirmation of 44 inflammatory signature genes in the DC line D1 and the absence of this signature in MT2 cells. Both cell lines were treated with LPS $(10 \mu \mathrm{g} / \mathrm{ml})$ and $10^{-8} \mathrm{M}$ dexamethasone (DEX) for $24 \mathrm{~h}$. Data are presented as mean fold changes in classifier gene transcript levels in three independent experiments per group.

doi:10.1371/journal.pone.0009404.g005

receptors and DC activation. Dexamethasone, Ill0 and vitamin D were used as typical anti-inflammatory stimuli. They were generally classified as non activating signals. By contrast, TLR ligands and whole bacteria, which are widely recognized as inflammatory signals, were classified as such by this system. The signature expression profile identified here consists of 44 highly predictive genes. These 44 genes provide a unique gene expression profile indicative of activation in DCs and providing important biological insight into the host response mediated by DCs. Genes already identified as involved in inflammation and DC activation were selected, including those encoding the interleukins Il6, Il12b and Illb [55], the chemokine Ccl22 [56], the membrane molecules Cd40, Gd83, Cd86, Icam1, and Ccr7 and the transcription factors Stat5a and Irfo, although the precise role of Irfo in DC activation is currently unknown.

Some of the genes selected have no known role in inflammation. For example, the Pdzklipl gene encodes a protein associated with various tumors when abundant. This protein seems to play a role in Akt activation and its gene was strongly induced by $L$. monocytogenes and LPS, whereas no overexpression was associated with poly I:C treatment. Thus, the induction of this gene is dependent on surface TLR stimulation. Rab20 encodes a protein 
D1

$\mathrm{CD}_{11 \mathrm{c}^{+}}$

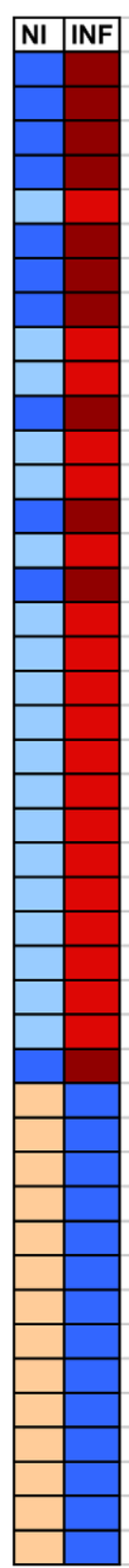

\begin{tabular}{|c|c|c|c|c|}
\hline Gene Name & DEX & LPS & DEX & LPS \\
\hline IL-6 & 0,61 & 195,66 & 0,24 & 4,33 \\
\hline IL12B & 0,23 & 139,32 & 0,74 & 0,52 \\
\hline PDZK1Ip1 & 0,98 & 32,59 & 0,11 & 81,81 \\
\hline IL-4I1 & 0,43 & 20,73 & 0,36 & 5,50 \\
\hline CCL22 & 0,18 & 16,14 & 0,60 & 3,93 \\
\hline CD83 & 0,50 & 16,06 & 0,34 & 2,35 \\
\hline GADD45B & 0,80 & 14,90 & 0,50 & 12,83 \\
\hline IL1B & 0,16 & 14,57 & 0,27 & 8,10 \\
\hline CD40 & 0,53 & 13,10 & 0,60 & 6,45 \\
\hline RAB20 & 0,48 & 11,52 & 0,70 & 7,36 \\
\hline CCR7 & 0,44 & 11,38 & 0,46 & 23,56 \\
\hline TRAF1 & 0,57 & 10,15 & 0,56 & 3,43 \\
\hline STAT5A & 0,88 & 7,38 & 0,69 & 5,74 \\
\hline ISG15 & 0,31 & 5,07 & 0,50 & 65,98 \\
\hline NFKBIA & 0,77 & 4,48 & 0,63 & 6,75 \\
\hline IRF8 & 0,25 & 3,92 & 0,90 & 0,80 \\
\hline ICAM1 & 0,95 & 3,83 & 0,64 & 4,43 \\
\hline NFKBIB & 0,55 & 3,38 & 0,79 & 3,91 \\
\hline TNFRSF1B & 0,58 & 2,51 & 0,54 & 3,37 \\
\hline SQTM1 & 0,94 & 2,16 & 0,83 & 3,18 \\
\hline SKIL & 0,76 & 1,97 & 0,44 & 1,82 \\
\hline GNAI3 & 0,88 & 1,93 & 0,91 & 1,85 \\
\hline NFKB1 & 0,63 & 1,83 & 1,26 & 0,92 \\
\hline CLIC4 & 0,79 & 1,55 & 0,48 & 14,78 \\
\hline TAP1 & 0,57 & 1,42 & 0,66 & 2,47 \\
\hline PSME2B-PS & 0,46 & 1,41 & 0,50 & 2,94 \\
\hline ANXA4 & 0,51 & 1,28 & 0,62 & 7,16 \\
\hline DNAJB6 & 0,81 & 1,25 & 0,71 & 1,49 \\
\hline TRAFD1 & 0,64 & 1,16 & 1,01 & 4,74 \\
\hline SERPINB9 & 0,31 & 0,73 & 0,36 & 9,18 \\
\hline EIF4EBP2 & 0,75 & 0,63 & 0,76 & 0,41 \\
\hline TSPAN8 & 2,38 & 0,50 & 0,08 & 0,05 \\
\hline CCNB2 & 1,01 & 0,45 & 1,06 & 0,34 \\
\hline ZNRF2 & 0,82 & 0,45 & 0,80 & 0,24 \\
\hline IL18R1 & 1,87 & 0,41 & 0,51 & 0,78 \\
\hline TEP1 & 0,68 & 0,40 & 0,64 & 0,41 \\
\hline HDAC5 & 0,95 & 0,39 & 0,78 & 0,18 \\
\hline KIF20A & 1,22 & 0,36 & 1,36 & 0,68 \\
\hline H2-DMa & 1,05 & 0,34 & 2,17 & 0,09 \\
\hline CDC20 & 1,03 & 0,31 & 0,85 & 0,31 \\
\hline TXNDC16 & 1,12 & 0,28 & 0,88 & 0,10 \\
\hline SGPP1 & 1,34 & 0,26 & 0,82 & 0,25 \\
\hline MAN2B1 & 0,93 & 0,22 & 0,70 & 0,10 \\
\hline IL1RL1 & 1,28 & 0,07 & 0,54 & 1,26 \\
\hline
\end{tabular}

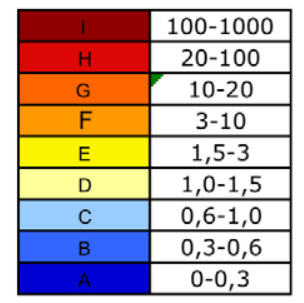

Figure 6. In vivo validation of the DC-specific inflammatory signature. C57BL/6 mice were treated with LPS and, after $5 \mathrm{~h}, \mathrm{CD} 11 \mathrm{c}+$ cells were isolated and tested for the inflammatory signature. Data are presented as mean fold changes in classifier gene transcript levels in three independent experiments.

doi:10.1371/journal.pone.0009404.g006

that regulates intracellular trafficking and may play an important role in inflammation. Rab20 has been shown to interact with connexin 45 [43]. Il4il was recently identified as an oxidize active against $l$-amino acids with potential effects on lymphocyte proliferation. It is strongly induced by $\mathrm{DC}$ activation.

The genes encoding proteins involved in the NF-kB pathway were more strongly induced by bacteria than TLR ligands. Inhibitor genes, such as Nfkbia and Nfkbib, were also overexpressed after stimulation with bacteria, consistent with the activation of regulatory mechanisms that control the inflammation. The downregulated genes include a large proportion of membrane proteins, such as Il18r1, Illrl1, Tspan8 and Tm7sf3, and genes encoding proteins with enzymatic activity, such as Man2b1 (an m-mannosidase), Lta4h (leukotriene A4 hydrolase), Txndc16 (thioredoxin domain-containing 16), Sgppl (sphingosine1-phosphate phosphatase 1), Hdac5 (histone deacetylase 5). The role of this dowregulation is currently unknown and requires further investigation.

We used the dendritic cell line D1 to optimize the sensitivity and precision of our gene expression profiling. We decided to determine an inflammation signature for DCs rather than for any other type of leukocyte, because DCs link innate and adaptive 
immunity [57]. The prediction of DC activation state is therefore of potential value for the testing of exogenous molecules with potential anti-inflammatory or adjuvant activity in DCs, to favor the repression or induction of T-cell responses. We validated the inflammatory signature in vivo, by testing the response in splenic DCs from mice treated with LPS and dexamethasone. Most of the genes $(80 \%)$ studied successfully characterized the activation state of splenic DCs, and differentiated the profile of these cells from that of DCs derived from mice treated with dexamethasone.

In conclusion, we used a meta-analysis of microarray data to identify gene modules predictive of DC activation. Accuracy and simplicity are essential characteristics of predictors for molecular assays. The predictive accuracy of predictors generally ranges from $65 \%$ to $100 \%$ (mean, $82 \%$ ) [58]. It is therefore important to identify the best way to select a suitable classifier for data, to maximize accuracy. In this study we used random forest methods for the selection of genes and the classification of microarray data [54,59]. The potential of array-based multidimensional predictors to outperform traditional parameters is increasing for biomarker discovery. The number of array-based studies is likely to increase exponentially, particularly in the field of inflammatory diseases. Such studies have been widely used for cancer classification $[60,61]$. In this study, we identified and validated a prognostic gene expression signature in DCs associated with inflammation. The signaling events affected by many of the genes in this signature occur in pathways essential for the immune response and cell activation. These genes may therefore be suitable targets, alone or in combination, for trials of anti-inflammatory and adjuvant treatments. We have demonstrated that a genome-wide systems biology approach may have advantages over traditional methods for biomarker discovery. Moreover, the small number of genes in our signature makes it possible to use simple, conventional assays, such as quantitative reverse transcriptase-polymerase chain reaction [62]. The increasing availability of laboratory diagnosis by polymerase chain reaction has opened up new possibilities for genomic testing based on the use of genetic signatures, in routine clinical conditions.

\section{Materials and Methods}

\section{Cell Culture}

D1 cells [29] were maintained in vitro in Iscove's modified Dulbecco's medium (IMDM, Euroclone) supplemented with 10\% heat-inactivated fetal bovine serum (Gibco, origin: Australia), $100 \mathrm{IU} / \mathrm{ml}$ penicillin, $100 \mu \mathrm{g} / \mathrm{ml}$ streptomycin, $2 \mathrm{mM}$ L-glutamine (all from Euroclone) and $50 \mu \mathrm{M} \beta$-mercaptoethanol (Sigma) plus 30\% R1 medium (supernatant from NIH3T3 fibroblasts transfected with GM-CSF).

MT2 cells are immortalized macrophages. They were derived from mouse thymus as previously described [47]. They were cultured in IMDM (Euroclone) supplemented with 5\% heatinactivated fetal bovine serum, $100 \mathrm{IU} / \mathrm{ml}$ penicillin, $100 \mu \mathrm{g} / \mathrm{ml}$ streptomycin, $2 \mathrm{mM}$ L-glutamine (all from Euroclone) and $50 \mu \mathrm{M}$ $\beta$-mercaptoethanol (Sigma).

\section{Microarray Dataset}

We obtained published gene expression datasets for microarray experiments performed with Dl cells, dexamethasone $\left(10^{-8} \mathrm{M}\right)$, the live microorganisms Schistosoma mansoni (MOI 1:200 parasites/ cell) and Leishmania mexicana (MOI 1:8) [23,30,31]. All the other samples were prepared specifically for this study. D1 cells were infected with Listeria monocytogenes EGD (MOI 1:20; provided by P. Cossard, Pasteur Institute, France) or treated with various TLR agonists: rLPS (10 $\mu \mathrm{g} / \mathrm{ml}$, Alexis, serotype R515), CpG (10 $\mu \mathrm{g} / \mathrm{ml}$,
Sigma), poly I:C (20 $\mu \mathrm{g} / \mathrm{ml}$, Amersham), Pam3Cys (1 $\mu \mathrm{M}$, Sigma) and zymosan ( $500 \mathrm{ng} / \mathrm{ml}$, Sigma). In summary, the data set is composed by: a) 14 untreated samples; b) 10 samples each of $\mathrm{CpG}$, Listeria monocytogenes, Pam3cis and polyI:C at time points $2 \mathrm{~h}, 4 \mathrm{~h}$, $8 \mathrm{~h}, 12 \mathrm{~h}$ and $24 \mathrm{~h}$ in duplicates; c) 8 samples each of Leishmania amastigote, Leishmania promastigote, Shistosoma SLA, Shistosoma EGGS and LPS at the time points $4 \mathrm{~h}, 8 \mathrm{~h}, 12 \mathrm{~h}$ and $24 \mathrm{~h}$ in duplicates; d) 6 samples of dexamethasone treated cells for the time points $4 \mathrm{~h}, 8 \mathrm{~h}$ and $24 \mathrm{~h}$ in duplicates; e) 15 zymosan treated samples at time points $2 \mathrm{~h}, 4 \mathrm{~h}, 8 \mathrm{~h}, 12$, and $24 \mathrm{~h}$ in triplicates. The data set is composed in total of 115 microarrays.

\section{Microarray Assay}

We harvested $10^{7} \mathrm{Dl}$ cells in the immature state or after $4 \mathrm{~h}$, $8 \mathrm{~h}, 12 \mathrm{~h}$ or $24 \mathrm{~h}$ of stimulation. Total RNA was isolated with Trizol Reagent (Invitrogen, Life Technologies, Karlruhe, Germany) and purified on a Qiagen RNeasy column (Qiagen, Hilden, Germany) to remove small fragments. RNA quality was assessed on an Agilent 2100 Bioanalyzer RNA 6000 Nano LabChip (Agilent Technologies, Palo Alto, CA). Only samples with intact total RNA profiles (retention of both ribosomal bands and the broad central peak of mRNA) were used for the microarray and quantitative RT-PCR gene expression analyses. In vitro transcription (IVT) products were generated and oligonucleotide array hybridization and scanning were carried out according to the instructions supplied by Affymetrix (Santa Clara, CA). We used 10 to $16 \mu \mathrm{g}$ of total RNA from each sample and T7-linked oligo-dT primers for first-strand cDNA synthesis. The fragmented biotinylated cDNA $(15 \mu \mathrm{g})$ was hybridized onto the MG-U74Av2 GeneChip (Affymetrix), using the recommended procedures for prehybridization, hybridization, washing and staining with streptavidin-phycoerythrin (SAPE).

Microarray Data Analysis and Supervised Class Prediction

Array images were analyzed with the RMA algorithm [33]. Samples displaying a signal ratio $>3.0$ for the $\beta$-actin and GAPDH probe sets were considered to be poor-quality targets and were excluded from the dataset.

The final dataset contained the results for 115 arrays (79 DC samples subjected to pro-inflammatory stimuli and 36 samples with anti-inflammatory reagents). A single log scale normalized expression measure for each probe set was obtained from the lowlevel data files (CEL files), by the robust multiarray analysis (RMA) procedure [33]. The data were subjected to Z-score-based transformation. A diagnostic model was obtained by applying the random forest (RF) method to the training set [54]. The model was based on 1000 bootstrap samples of the training set, with 1000 classification trees generated with a view to classifying cases as "inflammatory" and "not-inflammatory" on the basis of microarray gene expression measurements. RF is a method of the "decision tree classifiers" family, but it works on a collection of trees (a 'forest') rather than a single tree. In a decision tree, each node represents an attribute - in our case, the probeset - and the terminal nodes (the 'leaves') represent the attribute producing the best separation between the classes - ("inflammatory" and "not inflammatory" in this analysis) of a dataset. RF feeds each tree with an independent subset of attributes from a training set and individual instances are classified by a voting procedure, with the majority of the decision trees in the collection indicating the appropriate classification. Finally, during the classification process, $\mathrm{RF}$ determines the relative importance of each attribute, through various methods, such as calculation of the Gini Index, which assesses the importance of the variable and carries out accurate variable selection. 


\section{Quantitative Real-Time Polymerase Chain Reaction (qRT- PCR)}

D1 cells were infected with Listeria monocytogenes EGD (multiplicities of infection, MOI, 1:20) and Lactobacillus paracasei (MOI 1:1000) or were treated with various stimuli: sLPS $(10 \mu \mathrm{g} / \mathrm{ml}$, Alexis, serotype SO55:B5), poly I:C $(20 \mu \mathrm{g} / \mathrm{ml}$, Amersham), zymosan (500 ng/ml, Sigma), dexamethasone $\left(10^{-8} \mathrm{M}\right.$, Sigma), vitamin D (10 ${ }^{-8} \mathrm{M}$, Sigma), IL-10 (50 ng/ml, Immunok), IFN $\alpha$ (1000 U/ml, PBL Biomedical Laboratories) and Nimesulide (10 $\mu \mathrm{M}$, Cayman).

We harvested $5 \times 10^{6} \mathrm{Dl}$ cells either at $0 \mathrm{~h}$ or after $24 \mathrm{~h}$ of stimulation. Total RNA was isolated with Trizol Reagent (Invitrogen) and purified on a Qiagen RNeasy column (Mini kit, Qiagen). DNase digestion was carried out in the column during RNA extraction (RNase-free DNase Set, Qiagen). RNA quantity and quality was evaluated spectrophotometrically (NanoDrop ND1000 Spectrophotometer, Thermo Scientific). We reverse transcribed $1 \mu \mathrm{g}$ of total RNA with random primers (High Capacity cDNA Reverse Transcription Kit, Applied Biosystems). Quantitative RT-PCR (qRT-PCR) was performed on $10 \mathrm{ng}$ of total cDNA from independent samples, using primer sets specific for 54 selected genes and the 18 s housekeeping gene. qRT-PCR was carried out on a 7500 machine (Applied Biosystems), with Power SYBR Green PCR Master Mix (Applied Biosystems). Assays were carried out in duplicate. Primers were designed with Primer3 software (http://frodo.wi.mit.edu/) and checked with other tools (BLAST, http://blast.ncbi.nlm.nih.gov/Blast.cgi; m-fold, http:// mfold.bioinfo.rpi.edu/cgi-bin/dna-forml.cgi; IDT oligo analyzer,http://eu.idtdna.com/analyzer/Applications/OligoAnalyzer/ ). Primers were validated, and only primers with an amplification efficiency of 85 to $115 \%$ were accepted (Primm srl, Italy). Primer sequences are reported in Figure S4. The raw data (Ct, threshold cycle) were obtained with Applied Biosystems software. Relative mRNA levels were calculated by the $2^{-\Delta \Delta \mathrm{Ct}}$ method $(\Delta \mathrm{Ct}=$ $\left.\mathrm{Ct}_{\text {target }}-\mathrm{Ct}_{18 \mathrm{~s}}, \Delta \Delta \mathrm{Ct}=\Delta \mathrm{Ct}_{\text {stimulated }}-\Delta \mathrm{Ct}_{\text {not treated }}\right)$, using $18 \mathrm{~s}$ as the housekeeping gene.

\section{In Vivo Experiment}

Three mice per group of six-week-old C57BL/6 were injected with rLPS (50 $\mu \mathrm{g} /$ mouse, Alexis, serotype R515), dexamethasone (50 $\mu \mathrm{g} /$ mouse, Sigma), or with PBS as a control. The spleen was removed five hours later, and CD1 $1 \mathrm{c}^{+}$cells (DCs) were purified by magnetic bead separation (Miltenyi Biotec). C57BL/6 mice were purchased from Charles River and were maintained in our animal facility at the University of Milano-Bicocca. The in vivo experiment has been repeated two times. All experiments were performed using protocols approved by University of Milano-Bicocca Animal Care and Use Committee. Mice were housed in containment facilities of the animal facility and maintained on a regular 12:12 hour light:dark cycle with food and water ad libitum.

\section{References}

1. Steinman RM, Banchereau J (2007) Taking dendritic cells into medicine. Nature 449: 419-426.

2. Foti M, Granucci F, Ricciardi-Castagnoli P (2004) A central role for tissueresident dendritic cells in innate responses. Trends Immunol 25: 650-654.

3. Foti M, Granucci F, Ricciardi-Castagnoli P (2006) Dendritic cell interactions and cytokine production. Ernst Schering Res Found Workshop. pp 61-80.

4. Akira S, Takeda K, Kaisho T (2001) Toll-like receptors: critical proteins linking innate and acquired immunity. Nat Immunol 2: 675-680.

5. Medzhitov R, Janeway C, Jr. (2000) Innate immunity. N Engl J Med 343: 338-344.

6. Marshak-Rothstein A (2006) Toll-like receptors in systemic autoimmune disease. Nat Rev Immunol 6: 823-835.

7. Tsan MF, Gao B (2004) Endogenous ligands of Toll-like receptors. J Leukoc Biol 76: 514-519.

\section{Supporting Information}

Figure S1 Training and test sets, as used for the development of a classifier for the predictive analysis of microarrays. All samples were chosen based on the stimulus used for DC activation. The classifier, the random forest, was developed on the basis of two thirds of the samples (77 samples) and was then validated on the remaining one third (38 samples).

Found at: doi:10.1371/journal.pone.0009404.s001 (0.36 MB TIF)

Figure S2 Selection of genes discriminating between DC phenotypes. A) We investigated the predictive value of genes by calculating the median level of expression for the gene in the inflamed and non inflamed samples (LPS, PolyI:C, zymosan, dexamethasone, IL-10 and vitamin D) and then calculating mean expression levels for that gene. B-C) These values were used to assess whether, for a particular stimulus (Listeria monocytogenes, Lactobacillus paracasei, nimesulide or IFNÎt), the expression level of the gene concerned could be used to assign the sample to the correct class. A score of 1 was assigned if the expression level exceeded the mean value for inflammatory treatment or was below the mean level for anti-inflammatory treatment. A score of 0 was assigned in all other cases.

Found at: doi:10.1371/journal.pone.0009404.s002 (10.47 MB TIF)

Figure S3 Selection of genes discriminating between different DC phenotypes in vitro and in vivo. Class predictor genes were identified on the basis of their mean levels of expression with known stimuli and their classification performance was determined in MT2 cells (A) and in ex vivo CD11c+ cells derived from the spleens of mice treated with LPS (B).

Found at: doi:10.1371/journal.pone.0009404.s003 (1.16 MB TIF)

Figure S4 Primer sequences of house keeping and 54 genes used.

Found at: doi:10.1371/journal.pone.0009404.s004 (0.03 MB XLS)

\section{Acknowledgments}

We would like to thank everyone at the Genopolis Consortium for their contribution to microarray experiments and bioinformatics analysis. We are grateful to prof. P. Cossard at the Pasteur Institute, France, for providing the Listeria monocytogenes strains.

\section{Author Contributions}

Conceived and designed the experiments: FG PR-C MF. Performed the experiments: AT AR. Analyzed the data: AT OB AR MF. Contributed reagents/materials/analysis tools: OB. Wrote the paper: MF. Contributed to obtaining funding: MF PR-C.
8. Banchereau J, Steinman RM (1998) Dendritic cells and the control of immunity. Nature 392: 245-252.

9. Hyatt G, Melamed R, Park R, Seguritan R, Laplace C, et al. (2006) Gene expression microarrays: glimpses of the immunological genome. Nat Immunol 7: 686-691.

10. Yamagata T, Benoist C, Mathis D (2006) A shared gene-expression signature in innate-like lymphocytes. Immunol Rev 210: 52-66.

11. Shaffer AL, Rosenwald A, Hurt EM, Giltnane JM, Lam LT, et al. (2001) Signatures of the immune response. Immunity 15: 375-385.

12. Hutton JJ, Jegga AG, Kong S, Gupta A, Ebert C, et al. (2004) Microarray and comparative genomics-based identification of genes and gene regulatory regions of the mouse immune system. BMC Genomics 5: 82.

13. Alizadeh AA, Eisen MB, Davis RE, Ma C, Lossos IS, et al. (2000) Distinct types of diffuse large B-cell lymphoma identified by gene expression profiling. Nature 403: 503-511. 
14. Golub TR, Slonim DK, Tamayo P, Huard C, Gaasenbeek M, et al. (1999) Molecular classification of cancer: class discovery and class prediction by gene expression monitoring. Science 286: 531-537.

15. Ramaswamy S, Ross KN, Lander ES, Golub TR (2003) A molecular signature of metastasis in primary solid tumors. Nat Genet 33: 49-54.

16. van 't Veer LJ, Dai H, van de Vijver MJ, He YD, Hart AA, et al. (2002) Gene expression profiling predicts clinical outcome of breast cancer. Nature 415: $530-536$.

17. Wang Y, Klijn JG, Zhang Y, Sieuwerts AM, Look MP, et al. (2005) Geneexpression profiles to predict distant metastasis of lymph-node-negative primary breast cancer. Lancet 365: 671-679.

18. Ein-Dor L, Kela I, Getz G, Givol D, Domany E (2005) Outcome signature genes in breast cancer: is there a unique set? Bioinformatics 21: 171-178.

19. Symmans WF, Liu J, Knowles DM, Inghirami G (1995) Breast cancer heterogeneity: evaluation of clonality in primary and metastatic lesions. Hum Pathol 26: 210-216.

20. Granucci F, Vizzardelli C, Pavelka N, Feau S, Persico M, et al. (2001) Inducible IL-2 production by dendritic cells revealed by global gene expression analysis. Nat Immunol 2: 882-888.

21. McIlroy D, Tanguy-Royer S, Le Meur N, Guisle I, Royer PJ, et al. (2005) Profiling dendritic cell maturation with dedicated microarrays. J Leukoc Biol 78: 794-803.

22. Schoeters E, Nuijten JM, Van Den Heuvel RL, Nelissen I, Witters H, et al. (2006) Gene expression signatures in CD34+-progenitor-derived dendritic cells exposed to the chemical contact allergen nickel sulfate. Toxicol Appl Pharmacol 216: 131-149.

23. Vizzardelli C, Pavelka N, Luchini A, Zanoni I, Bendickson L, et al. (2006) Effects of dexamethazone on LPS-induced activationand migration of mouse dendritic cells revealed by a genome-wide transcriptional analysis. Eur J Immunol 36: 1504-1515.

24. Zilliox MJ, Parmigiani G, Griffin DE (2006) Gene expression patterns in dendritic cells infected with measles virus compared with other pathogens. Proc Natl Acad Sci U S A 103: 3363-3368.

25. Ju XS, Zenke M (2004) Gene expression profiling of dendritic cells by DNA microarrays. Immunobiology 209: 155-161.

26. Zhong W, Fei M, Zhu Y, Zhang X (2009) Transcriptional profiles during the differentiation and maturation of monocyte-derived dendritic cells, analyzed using focused microarrays. Cell Mol Biol Lett 14: 587-608.

27. Lehtonen A, Ahlfors H, Veckman V, Miettinen M, Lahesmaa R, et al. (2007) Gene expression profiling during differentiation of human monocytes to macrophages or dendritic cells. J Leukoc Biol 82: 710-720.

28. Zaslona Z, Wilhelm J, Cakarova L, Marsh LM, Seeger W, et al. (2009) Transcriptome profiling of primary murine monocytes, lung macrophages and lung dendritic cells reveals a distinct expression of genes involved in cell trafficking. Respir Res 10: 2.

29. Winzler C, Rovere P, Rescigno M, Granucci F, Penna G, et al. (1997) Maturation stages of mouse dendritic cells in growth factor-dependent long-term cultures. J Exp Med 185: 317-328.

30. Trottein F, Pavelka N, Vizzardelli C, Angeli V, Zouain CS, et al. (2004) A type I IFN-dependent pathway induced by Schistosoma mansoni eggs in mouse myeloid dendritic cells generates an inflammatory signature. J Immunol 172: 3011-3017.

31. Aebischer T, Bennett CL, Pelizzola M, Vizzardelli C, Pavelka N, et al. (2005) A critical role for lipophosphoglycan in proinflammatory responses of dendritic cells to Leishmania mexicana. Eur J Immunol 35: 476-486.

32. Pavelka N, Pelizzola M, Vizzardelli C, Capozzoli M, Splendiani A, et al. (2004) A power law global error model for the identification of differentially expressed genes in microarray data. BMC Bioinformatics 5: 203.

33. Irizarry RA, Hobbs B, Collin F, Beazer-Barclay YD, Antonellis KJ, et al. (2003) Exploration, normalization, and summaries of high density oligonucleotide array probe level data. Biostatistics 4: 249-264.

34. Abraham SM, Lawrence T, Kleiman A, Warden P, Medghalchi M, et al. (2006) Antiinflammatory effects of dexamethasone are partly dependent on induction of dual specificity phosphatase 1. J Exp Med 203: 1883-1889.

35. Alroy I, Towers TL, Freedman LP (1995) Transcriptional repression of the interleukin-2 gene by vitamin D3: direct inhibition of NFATp/AP-1 complex formation by a nuclear hormone receptor. Mol Cell Biol 15: 5789-5799.

36. Mathieu C, Jafari M (2006) Immunomodulation by 1,25-dihydroxyvitamin D3: therapeutic implications in hemodialysis and renal transplantation. Clin Nephrol 66: 275-283.

37. van Etten E, Mathieu C (2005) Immunoregulation by 1,25-dihydroxyvitamin D3: basic concepts. J Steroid Biochem Mol Biol 97: 93-101.

38. Bhattacharyya S, Sen P, Wallet M, Long B, Baldwin AS, Jr., et al. (2004) Immunoregulation of dendritic cells by IL-10 is mediated through suppression of the PI3K/Akt pathway and of IkappaB kinase activity. Blood 104: 1100-1109.
39. Kong J, Grando SA, Li YC (2006) Regulation of IL-1 family cytokines ILlalpha, IL-1 receptor antagonist, and IL-18 by 1,25-dihydroxyvitamin D3 in primary keratinocytes. J Immunol 176: 3780-3787.

40. ZhangJZ, Maruyama K, Ono I, Iwatsuki K, Kaneko F (1994) Regulatory effects of 1,25-dihydroxyvitamin D3 and a novel vitamin D3 analogue MC903 on secretion of interleukin-1 alpha (IL-1 alpha) and IL-8 by normal human keratinocytes and a human squamous cell carcinoma cell line (HSC-1). J Dermatol Sci 7: 24-31.

41. Lacey DL, Grosso LE, Moser SA, Erdmann J, Tan HL, et al. (1993) IL-1induced murine osteoblast IL-6 production is mediated by the type 1 IL-1 receptor and is increased by 1,25 dihydroxyvitamin D3. J Clin Invest 91: 1731-1742.

42. Prehn JL, Jordan SC (1989) Incubation of T cell or monocytic cell lines with 1,25-dihydroxyvitamin D3 before mitogen stimulation potentiates IL-2 and IL-1 beta mRNA levels. Transplant Proc 21: 90-91.

43. Das Sarma J, Kaplan BE, Willemsen D, Koval M (2008) Identification of rab20 as a potential regulator of connexin 43 trafficking. Cell Commun Adhes 15: 65-74.

44. Luft T, Luetjens P, Hochrein H, Toy T, Masterman KA, et al. (2002) IFN-alpha enhances CD40 ligand-mediated activation of immature monocyte-derived dendritic cells. Int Immunol 14: 367-380.

45. Svane IM, Nikolajsen K, Walter MR, Buus S, Gad M, et al. (2006) Characterization of monocyte-derived dendritic cells maturated with IFN-alpha. Scand J Immunol 63: 217-222.

46. Dillon S, Agrawal S, Banerjee K, Letterio J, Denning TL, et al. (2006) Yeast zymosan, a stimulus for TLR2 and dectin-1, induces regulatory antigenpresenting cells and immunological tolerance. J Clin Invest 116: 916-928.

47. Pirami L, Stockinger B, Corradin SB, Sironi M, Sassano M, et al. (1991) Mouse macrophage clones immortalized by retroviruses are functionally heterogeneous. Proc Natl Acad Sci U S A 88: 7543-7547.

48. Shyamsundar R, Kim YH, Higgins JP, Montgomery K, Jorden M, et al. (2005) A DNA microarray survey of gene expression in normal human tissues. Genome Biol 6: R22.

49. Whitney AR, Diehn M, Popper SJ, Alizadeh AA, Boldrick JC, et al. (2003) Individuality and variation in gene expression patterns in human blood. Proc Natl Acad Sci U S A 100: 1896-1901.

50. Yanai I, Benjamin H, Shmoish M, Chalifa-Caspi V, Shklar M, et al. (2005) Genome-wide midrange transcription profiles reveal expression level relationships in human tissue specification. Bioinformatics 21: 650-659.

51. Alon U, Barkai N, Notterman DA, Gish K, Ybarra S, et al. (1999) Broad patterns of gene expression revealed by clustering analysis of tumor and normal colon tissues probed by oligonucleotide arrays. Proc Natl Acad Sci U S A 96: 6745-6750.

52. Paik S, Tang G, Shak S, Kim C, Baker J, et al. (2006) Gene expression and benefit of chemotherapy in women with node-negative, estrogen receptorpositive breast cancer. J Clin Oncol 24: 3726-3734.

53. Allantaz F, Chaussabel D, Stichweh D, Bennett L, Allman W, et al. (2007) Blood leukocyte microarrays to diagnose systemic onset juvenile idiopathic arthritis and follow the response to IL-1 blockade. J Exp Med 204: 2131-2144.

54. Diaz-Uriarte R, Alvarez de Andres S (2006) Gene selection and classification of microarray data using random forest. BMC Bioinformatics 7: 3 .

55. Blanco P, Palucka AK, Pascual V, Banchereau J (2008) Dendritic cells and cytokines in human inflammatory and autoimmune diseases. Cytokine Growth Factor Rev 19: 41-52.

56. Ritter M, Goggel R, Chaudhary N, Wiedenmann A, Jung B, et al. (2005) Elevated expression of TARC (CCL17) and MDC (CCL22) in models of cigarette smoke-induced pulmonary inflammation. Biochem Biophys Res Commun 334: 254-262.

57. Foti M, Ricciardi-Castagnoli P, Granucci F (2007) Gene expression profiling of dendritic cells by microarray. Methods Mol Biol 380: 215-224.

58. Jiang W, Varma S, Simon R (2008) Calculating confidence intervals for prediction error in microarray classification using resampling. Stat Appl Genet Mol Biol 7: Article8.

59. Yang F, Wang HZ, Mi H, Lin CD, Cai WW (2009) Using random forest for reliable classification and cost-sensitive learning for medical diagnosis. BMC Bioinformatics 10 Suppl 1: S22.

60. Huang LT (2009) An integrated method for cancer classification and rule extraction from microarray data. J Biomed Sci 16: 25.

61. Peng Y, Li W, Liu Y (2007) A hybrid approach for biomarker discovery from microarray gene expression data for cancer classification. Cancer Inform 2: 301-311.

62. Lossos IS, Czerwinski DK, Alizadeh AA, Wechser MA, Tibshirani R, et al. (2004) Prediction of survival in diffuse large-B-cell lymphoma based on the expression of six genes. N Engl J Med 350: 1828-1837. 